\title{
Impact of Owners'-Managers' Demographic Characteristics on the Performance of MSEs in Ethiopia
}

\author{
Abiot Animaw Semegn ${ }^{1} \quad$ Narendra Kumar Bishnoi ${ }^{2}$ \\ 1.Research Scholar, Department of Economics, Guru Jambheshwar University of Science \& Technology, Hisar \\ 2.Professor, Department of Economics, Guru Jambheshwar University of Science \& Technology, Hisar
}

\begin{abstract}
This research paper examines the effect of MSEs owners/managers demographic characteristics on the performance of the micro and small enterprise (MSEs) in Ethiopia. 340 MSEs owners'-managers were randomly selected, and the survey method was used. Both descriptive and inferential analysis was used. Average Sales volume and Employment size were used to measure performances of MSEs. The findings suggest that gender and age of owners/managers have a positive and significant effect on sales and employment performance of MSEs, while years of schooling has a positive and significant effect on the sales performance of MSEs, but not on employment performance. The paired t-test result indicates that there is a significant difference between the sales and employment performances of male-owned and female-owned enterprises. The study concluded that owners/managers demographic characteristics have a positive influence on the employent and sales performance of MSEs. It is suggested that micro and small enterprises development agencies and microfinance institutions should revise the modalities of training delivered to MSEs operators and should strengthen their existing regulations and policies to empower women.
\end{abstract}

Keywords: Owner-manager, demographic factors, MSEs performance, regression, Ethiopia

DOI: $10.7176 / \mathrm{EJBM} / 12-35-01$

Publication date: December $31^{\text {st }} 2020$

\section{Background}

Small firms create more than $50 \%$ of employment opportunities with fewer than 100 employees in developing countries, provide two-thirds of jobs in all countries and consisting of over $90 \%$ of the private sector among developing countries. In addition to their significant contribution to employment creation, the vitality of SMEs is important for comprehensive economic growth, source of innovation and broadening of the economic base (Ayyagari, Asli, \& Maksimovic, 2007). The welfare, standard of living, income levels and social stability of people across the world can be improved by the employment opportunities created by the SMEs (Amoah \& Amoah, 2018). The SMEs are attributed with creating the greatest share of employment, industrial production and exports (Katua, 2014).

The SMEs sector has been given due attention by governments, policymakers, research scholars, academicians, and multilateral companies because SMEs utilize local raw materials, provide employment opportunity, stimulates rural and urban development, promotes entrepreneurship, uses optimum capital, provides inputs to large industries, act centre of skill and knowledge development (Taiwo, Ayodeji, \& Yusuf, 2013). Thus, SMEs are highly acknowledged in catalyzing economic development, create employment opportunities and becomes centre of innovation and invention in both developing and developed countries even if the role they played differs from country to country. The role of SMEs to employment and Gross Domestic Product varies between and across countries. Less than 10\% of GDP in developing countries and more than $50 \%$ of GDP in advanced countries is constituted by SMEs. About 45 per cent of total employment and 33 per cent of (GDP) in developing countries is offered by SMEs (Amoah \& Amoah, 2018). MSEs are critical in generating and supporting economic growth and fair distribution of development in both advanced and emerging countries. They play fundamental roles in generating employment for more labour, market base economic growth, reducing poverty and promoting democratization in developing countries (Anne, Gichuki, Njeru, \& Tirimba, 2014).

The focus of Ethiopia's MSE development is fast and sustainable economic growth, employment creation for unemployed and transforming an agricultural economy to an industrial economy. The Ethiopian MSEs development and promotion strategy focus and tiles the base for the development of the sector was launched in 1997. MSEs development holds a strategic place within Ethiopia's Industrial Development Strategy. The main emphasis of the MSE development strategy was to form a conducive situation for MSEs. MSEs, then, catalyze growth, produce sustainable employment opportunities, reinforce collaboration between MSEs, offer foundations for medium and large enterprises and encourage export. MSEs are the vital tools of job creation in urban centres, and job creation is the core of the country's development plan. In Ethiopia, the need to support MSEs development goes beyond the current priorities given to employment creation. Thus, priority is given to the MSEs sector as they are important vehicles for production and growth in the manufacturing sector (FeMSEDA, 2011).

The share of MSEs to GDP, Employment, Export, and total and new annual establishments are basic indicators to measure the size of MSEs. Despite MSEs are the target sector, its performance with its share to GDP, 
employment, and export and total manufacturing output was not known in Ethiopia (Assefa, Zerfu, \& Tekle, 2014). In the 2016/17 fiscal year, 157,768 new MSEs established and created employment opportunities for over 1.2 million youths, and over 7.1 billion ETB loans were disbursed. Of the total newly established MSEs, Oromia, Tigray, and the Amhara Regional States took of 31.3\%, 25.1\%, and 24.5\%, respectively, while Southern Nations Nationalities People Region (SNNPR) and Addis Ababa received $13 \%$ and 3.5\% of the MSEs. Of the total loans distributed, Amhara, Addis Ababa, and the Oromia Regional States received 38.9 \%, 23.2 \%, and $16 \%$ share, respectively, while Tigray and the SNNPR Regional States took $12.5 \%$ and $5.1 \%$ of the loans. The share of employment created in Oromia, SNNPR, and Amhara was 40.5 \%, $17.3 \%$, and $16 \%$, respectively, while $14 \%$ em-ployment created in Tigray and $6.9 \%$ in Addis Ababa (NBE,2016).

Even though the owners-managers of MSEs played a vital role in the success of firms, little attention was given in scientific research's relative to researches focus on business/firm and credit characteristics. The role of owners/managers in the growth of the firm was given insignificant attention and, in most studies, it was simply used in describing the demographic characteristics. The survival and sustainability of most of the MSEs rely on the role of owners/managers demographic factors. An entrepreneur is a person who organizes and runs a business venture and assumes much of the related risk. An entrepreneur makes fundamental decisions regarding price, quantity, quality, customer relations, branding, business expansion, and other strategic decisions (Frese, 2000). Therefore, the difference among the performance (failure/success) of MSEs may be owing to the differences in the individual demographic characteristics of SMEs owners/managers (Hall, 1995; Shane, 2007; Batsakis, 2014). Thus, the fundamental target of this research paper is to examine the effect of demographic characteristics the owners'-managers on the performance of MSEs.

\section{Literature Review}

\section{Concept of Micro and Small Enterprises}

The MSEs nomenclature is to mean Micro and Small Enterprises while SMEs is Small and Medium Enterprises such that an enterprise that is considered small and medium in one country is seen differently in another country. MSEs/SMEs are defined in terms of their annual turnover and number of employees in some countries whereas in other countries it can be defined in terms of total asset, capital investment and labour force employed. Employment and total asset are two operational definitions of SMEs in the Philippines (Aldaba, 2012). In Nigeria, SMEs are defined based on business turnover and employment (Oyelaran-Oyeyinka, 2006). Thus, the size of the labour force employed, total assets, annual turnover, and capital investments are the widely used indicators in the definitions MSEs. Accordingly, the FDRE, National MSEs policy and strategic document, (2012) indicate the definitions of MSEs based on nature of the sector the enterprise engages, employment and total asset as indicated in the table below.

Table 1: MSEs Definition in Ethiopia

\begin{tabular}{lllll}
\hline Size of enterprise & $\begin{array}{l}\text { Business } \\
\text { Sector }\end{array}$ & Employment & $\begin{array}{l}\text { Total asset } \\
\text { ETB }\end{array}$ & $\begin{array}{l}\text { Total asset } \\
\text { USD }\end{array}$ \\
\hline Microenterprise & Industry & $\leq 5$ & $\leq 100,000$ & $\leq 4,630$ \\
& Service & $\leq 5$ & $\leq 50,000$ & $\leq 2,310$ \\
\cline { 2 - 5 } Small enterprise & Industry & $6-30$ & $101,000-1,500,000$ & $4,630-69,500$ \\
& Service & $6-30$ & $50001-500,000$ & $2,310=23,150$ \\
\hline
\end{tabular}

Source:(FeMSEDA, 2011)

According to a study by (Kirby, 2003; Batsakis, 2014), owners/managers demographic characteristics, for example, education, experience, age, and family as key features of firm growth. the impact of an entrepreneur's demographic characteristics related to gender, marital status, age, year of schooling, and entrepreneurship training on the performance of MSEs are investigated.

\section{Gender and performance of MSEs}

It is mostly recognized that gender differences influence firm performance (Brush, 1992). However, the influence of gender on the performance of MSEs have not been fully explained. Most studies either unnoticed gender as a variable of interest or omitted females subjects in their investigation (Du Rietz \& Henrekson, 2000). Akabueze (2002) examined the factors affecting the performance of SMEs but did not include gender as a variable of interest. A study by Fapohunda (2013) indicates that SME owners business experience has mixed results on the performance. Female-owned enterprises are characterized by lower performance relative to the male-owned, and they are few (Gottschalk \& Niefert, 2012). Mba (2006) indicated that women entrepreneurs have less managerial and self-employment experience which suggests that they are likely to fail, while female entrepreneurs have better business-related experience than male entrepreneurs (Amobi, 2006). Thus, the following null hypothesis was formulated:

$\mathrm{H}_{0}$ : there is no significant difference between the performance of male and female-owned MSEs. 


\section{Education and performance of MSEs}

The objective of training/educating an entrepreneur is to make them responsible, risk-takers, make strategic decisions, and enable them to learn from achievements and failures (Tendai, 2014). In addition to this, business owners learn how to overcome the challenges that they may face. It also enhances entrepreneurial attitudes, growth of firms, and its achievements. Studies have shown varied results for the relationship between entrepreneurship training and entrepreneurial development. A study by Black, Noel and Wang (1999) suggested the association between business productivity and training was positive and feasible in large firms since these firms deliver extra training per worker than small firms. Entrepreneurship training is vital at the macro level since it drives economic growth through the accumulation of human capital (Bryan, 2006). The accumulation of capital contributes more to nonstop competitive advantage at the micro-levels (García, 2005; Bryan, 2006). Entrepreneurship and managerial training can enhance the skill gap of MSEs operators. Entrepreneurship training is the way to disseminate appropriate information to increase the performance of SMEs. Owner and managerial training help entrepreneurs to have exposure to the internal and external business environment. Thus, entrepreneurship and managerial training is given to micro and small enterprises contribute to improving the performance of firms (Mescon,1987; Webster, Walker \& Brown,2005). Knowledge acquired through entrepreneurship training increases business productivity and reduces failure (García, 2005; Mahmood \& Rosli, 2013).

\section{Age and performance of MSEs}

Studies show that the association between an entrepreneur's age and the performance of SMEs are contradictory. Studies by (Davidsson, 1991; Storey, 1994), indicated that firms that are managed by young owners or managers are more successful than older owners or manager because they have more liveliness, ambitions, commitment to work long hours whereas performance or advancement of firms is given little attention by older owners or managers as they are likely to have reached their final goals. On the other hand, studies by (Harada, 2003; Littunen \& Virtanen, 2006) shows SMEs managed by older owner/managers are more probably effective than those SMEs managed by younger owners or managers since older managers/owners have more experience and have passed many hindrances, and thus they are stronger and more confident.

\section{Entrepreneurship Training and Performance of MSEs}

Studies have shown a mixed relationship between entrepreneurship training and entrepreneurial development, they have not highlighted the role of entrepreneurship training and education on the performance of enterprises. A study by (Black et al., 1999), suggested the association between business productivity and training positive and feasible in large firms since these firms deliver extra training per worker than small firms. Training is important at the macro level since it drives economic growth through the accumulation of human (Lucas, 1993), while human capital is assumed to contribute a lot to nonstop competitive advantage at the micro-level (Koch \& McGrath, 1996). Based on this, the following hypothesis was developed;

H0: Access to entrepreneurship training influences positively performance of MSEs

\section{Method \\ Research Design and Approaches}

The researcher used a survey study design, which involved the collection of quantitative data from the Amhara National Regional State (ANRS) sampled MSEs managers/owners and MFIs managers'/loan officers. Qualitative research identifies people's experience, culture, opinions, attitudes, behaviour, and how people observe a problem or situation, while quantitative research is used to scrutinize the association between rigorous quantitative analysis (Creswell, 2014; Kothari, 2009).

\section{Sample and Sampling Procedures}

The target population of this study was the registered MSEs in ANRS and Amhara Credit and Saving Institution (ACSI). The sample size was determined using purposive and systematic random sampling approaches. Hence, Multi-stage sampling techniques were employed. First, the Amhara National Regional State was selected purposely because it ranked third in the concentration of MSEs and first in the amount of loan distributed at the national level in 2017/18. Second, from the ANRS, Zones and cities were selected based on the relative concentration of MSEs and the amount of loan given to MSEs. Hence, there are 25,441 registered MSE. Finally, from the legally registered MSEs,340 were randomly selected using Cochran (1977) sample size determination formula.

\section{Validity and Reliability}

Validity is the extent to which a test measures what we wish to measure while reliability has to do with the accuracy and precision of a measurement procedure. The questionnaire was given to experts that have better knowledge in the areas of research and small business development for content analysis. Their suggestions and comments were 
incorporated into the final document. According to Mugenda and Mugenda (2003), the reliability pre-test sample size can be between $1 \%$ and $10 \%$ of the total sample. Thus, $10 \%$ of the total sample was used as a pilot study to ensure reliability.

\section{Data collection and analysis}

Data were collected using self-administered structured questionnaires. The collected data were encoded and analyzed using statistical software Stata/SE14.0. Descriptive statistics such as mean, percentages, standard deviations, and inferential statistics (t-test and multiple regression) were calculated.

\section{Operationalization of Study Variables}

Performance of MSEs can be measured by using sales volume, size of employment, total assets, profit, market share and productivity (Atiase, Mahmood, \& Wang, 2019). The dependent variable which is the performance of MSEs in this research paper is proxied by sales volume and size of employees since they are the more objective indicators of firm performance. The explanatory variables are gender, marital status, age, years of schooling, and entrepreneurship training which are the demographic characteristics of owners or managers.

Table 2: Definition of variables

\begin{tabular}{|l|l|l|}
\hline Variable & $\begin{array}{l}\text { Type } \\
\text { variable }\end{array}$ & Measurement \\
\hline Performance of MSEs & Dependent & $\begin{array}{l}\text { It is continuous which is measured by the volume of sales and } \\
\text { number of employment }\end{array}$ \\
\hline Gender of MSEs & Explanatory & Dummy that is $1=$ male; $0=$ female \\
\hline $\begin{array}{l}\text { Age } \\
\text { owner/manager }\end{array}$ & Explanatory & Continuous i.e. level of education of owner/manager \\
\hline Year of schooling & Explanatory & Dummy that is $0=$ do not participate; $1=$ participate in training \\
\hline $\begin{array}{l}\text { Entrepreneurship } \\
\text { Training }\end{array}$ & Explanatory & Categorical variable where: $1=$ single; $2=$ married;3=divorced \\
\hline Marital status &
\end{tabular}

Source: owners computation,2019

\section{Analytical model specification}

To examine the impact of owners/managers demographic characteristics on the performance of MSEs, the study employed ordinary least square (OLS) regression analysis where the dependent variable was measured by the natural logarithm of average sales, and size of employment, while the explanatory variables were gender, owers/managers age, level of education, marital status, and entrepreneurship training. The predictors are selected from key demographic characteristics of entrepreneurs. The hypothesis was set to discover the degree to which demographic characteristics of managers/owners could improve the performance of MSEs in the study. The following multiple regression model was used to examine the effect of microcredit on the performance of MSEs: $\mathrm{P}=\alpha+\beta_{1} \mathrm{Gn}+\beta_{1}$ age $+\beta_{2} \mathrm{YS}+\beta_{3} \mathrm{~T}+\mathrm{MS}+\varepsilon$

Where $\mathrm{P}$ is the performance of MSEs (dependent variable) measured in terms of average sales volume and size of employment. The predictors are: age is which is MSEs owners/managers age, YS is years of schooling, T is access to entrepreneurship training, Gn is gender, and MS is marital status. $\alpha$ is constant which represents the performance of MSEs that is not influenced by explanatory variables in the model, and $\varepsilon$ is the error term.

\section{Data presentation and Analysis of Demographic characteristics of respondents}

The results from the study show that the majority (64 per cent) of respondents were male, while 36 per cent were female. The participation of female was less than that of men due to socio-cultural factors. The study also indicates that the average age of the owners/managers of MSEs was 26.5, with a standard deviation of 3.21. According to FeMSEDA (2011), youths are allowed and supported by the government to access credit from MFIs if their age is between 18 and 32. For those whose age is above 32, the government may not support the enterprise but can help them to access credit on their own. Besides, the study reveals that the mean level of schooling of the respondents was 9.4 years, with a standard deviation of 3.21, which shows that the average respondents can read and write so that it would be easier to them to manage their business. Furthermore, the finding from the study reveals that 42.3 per cent of respondents were single, while 52.94 per cent were married

The study also indicates that the average age of the sample MSEs owners/managers were 26.5 with a standard deviation of 3.215. The mean level of education of respondents 9.4 with a standard deviation of 3.423 with a maximum level of years of schooling of 17 years which is equivalent to MBA/MSC/five years of attending in university and a minimum of no attending of formal education. Table -3 also shows that the majority $(89.34 \%)$ of the MSEs owners/managers participated in entrepreneurship training, while $10.59 \%$ did not attend any form of entrepreneurship training. Regarding the form of the business size that the respondents engaged,38.82\% were 
micro-enterprises, while the majority $(61.18 \%)$ were small enterprises.

Table 3: Demographic characteristics of owners/managers of MSEs

\begin{tabular}{|c|c|c|c|c|c|}
\hline Variable & Observation & Mean & Std.Dev & Min & Max \\
\hline Age of owner & 340 & 26.5 & 3.215 & 18 & 34 \\
\hline Year of schooling & 340 & 9.4 & 3.423 & 0 & 17 \\
\hline Business age & 340 & 4.75 & 1.3635 & 2 & 9 \\
\hline Variable & Frequency & Percent & Cum.frequency & & \\
\hline \multicolumn{4}{|l|}{ Gender } & & \\
\hline Female & 124 & 36.47 & 36.47 & & \\
\hline Male & 216 & 63.53 & 100.00 & & \\
\hline \multicolumn{4}{|l|}{ Marital status } & & \\
\hline Single & 144 & 42.35 & 42.35 & & \\
\hline Married & 180 & 52.94 & 95.29 & & \\
\hline Divorced & 16 & 4.71 & 100.00 & & \\
\hline \multicolumn{4}{|l|}{ Training } & & \\
\hline Participate & 304 & 89.41 & 89.41 & & \\
\hline Do not participate & 36 & 10.59 & 100.00 & & \\
\hline \multicolumn{4}{|l|}{ Business size } & & \\
\hline Micro & 132 & 38.82 & 38.82 & & \\
\hline Small & 208 & 61.18 & 100 & & \\
\hline
\end{tabular}

Source: authors computation,2019

\section{The influence of gender on MSEs performance}

To test whether there is a significant difference between the average sales of female-owned and male-owned MSEs where the independent variable is sales volume which is continuous and the independent variable is the binary response, t-test was used. The Stata output of the independent t-test for equality of means of sales revenue is indicated in appendix-1. The mean value of sales revenue of female-owned enterprises was 120937.9ETB, while that of the male was 165414.5ETB with a standard deviation of 91671.93 and 105332.3, respectively. The p-value of the mean of (female)-mean of (male) is (0.0001) which was significant at a $95 \%$ confidence interval. This suggested that male-owned enterprises have registered more sales revenue relative to their female counterparts. The t-test results suggest that gender influences firm performance. In other words, the independent samples t-test results reveal that male-owned SMEs outperform female-owned SMEs. Relying on the independent samples t-test, the null hypothesis $\mathrm{H}_{0}$ is therefore rejected. Our findings are consistent with the results obtained by Shava \& Rungani (2016) who indicated that male-owned firms outperform female-owned business entities. This finding, therefore, confirms the existence of a gender gap concerning SME performance.

On the other hand, literature shows that the performance of female-owned enterprises are low relative to their male counterparts. Thus, an attempt was made to test whether there is a significant mean difference between the size of employment of male-owned and female-owned enterprise as indicated in appendix-2. The mean value of the employment level of female-owned enterprises was 3.5, while that of the male-owned is 4.7 with a standard deviation of 2.9 and 3.21, respectively. The p-value of the paired t-test result for equality of mean of employment is $(0.0005)$ which is statistically significant at $95 \%$ confidence interval. This shows that the average level of employment for male-owned MSEs are significantly greater than that of their female counter. The t-test results suggest that gender influences the level of firm employment. In other words, the independent samples t-test result reveal that male-owned SMEs outperform female-owned SMEs in terms of creating job opportunities. Relying on the independent samples t-test, the null hypothesis $\mathrm{H}_{0}$ is therefore rejected. Our findings are consistent with the results obtained by Shava \& Rungani (2016) who indicated that male-owned firms outperform female-owned business entities. This finding, therefore, confirms the existence of a gender gap about SME employment performance.

\section{Regression Estimation}

Multiple regression was used to scrutinize the effect of the demographic features of entrepreneurs on the performances of MSEs in Ethiopia. 
Table 4: Estimation of the effect of owner/manager demographic characteristics on the performance of MSEs

\begin{tabular}{|c|c|c|c|c|}
\hline Sale volume & Coefficient & $\begin{array}{l}\text { Robust } \\
\text { Std. Error }\end{array}$ & $\mathrm{t}$ & p-value \\
\hline Owners age & .0297 & .0096 & 3.08 & $0.002 * * *$ \\
\hline Year of schooling & .03495 & .0110 & 3.15 & $0.002 * * *$ \\
\hline Training (Yes ) & .1618 & .1019 & 1.59 & 0.114 \\
\hline Gender(male) & .2279 & .0739 & 3.08 & $0.002 * * *$ \\
\hline Marital status(single) & .1870 & .1272 & 1.47 & 0.143 \\
\hline Marital status(Married) & .1040 & .1209 & 0.86 & 0.390 \\
\hline Constant & 10.2953 & .2725 & 37.78 & 0.000 \\
\hline \multicolumn{5}{|l|}{ Employment } \\
\hline Age of owner & .0982 & .0455 & 2.16 & $0.032 * *$ \\
\hline Year of schooling & .0238 & .0506 & 0.47 & 0.638 \\
\hline Training (yes) & .4800 & 0.4415 & 1.09 & 0.278 \\
\hline Gender(male) & .9704 & .3659 & 2.65 & $0.008 * * *$ \\
\hline Marital status(single) & 2.7781 & .4572 & 6.08 & $0.000 * * *$ \\
\hline Marital status (Married) & 2.6226 & .4426 & 5.92 & $0.000 * * *$ \\
\hline Constant & -2.1067 & 1.2590 & -1.67 & 0.095 \\
\hline
\end{tabular}

Source: authors computation,2019

$* * *$ Sig at $1 \%$ level of significance, $* *$ sig at $5 \%$-the level of significance

Multiple regression analysis was applied to assess the effect of owners/managers demographic characteristics on the performance of MSEs. The dependent variable was the natural logarithm of the sales volume and size of employment. The explanatory variables are gender, marital status, owners/managers age, level of education, and managerial and entrepreneurship training. From the regression estimation in table-4, the study reveals that owners age, years of schooling, and gender (male) have a significant and positive effect on the sales performance of MSEs at $1 \%$ level of significance. The result indicated that if the age of owners/managers increases by 1 year, the sales performance of MSEs increases by $0.029 \%$, given all other factors constant. Similarly, if the level of schooling of owners/managers increases by 1 year, the sales performance of MSEs increases by $0.034 \%$. The probability of an increment in sales performance of MSEs increases by 0.2279 units if the MSEs are owned/managed by male relative to female, all other factors constant. On the other hand, the age of owner/manager, gender(male), and marital status both being single and married have a positive and significant effect on the employment performance of MSEs. If the age of owners/managers increases by 1 year, the employment performance of MSEs increases by 0.098 units. The probability of an increase in employment of MSEs increases by 0.9704 units if the firms are owned/managed by males than their counterpart females. Besides, the probability of an increase in employment performances increases with owners/managers who are single or married than those divorced.

Moreover, the study suggested that the owners or managers age and years of schooling influences the performance of the sales volume of MSEs. Even though $89 \%$ of the MSEs owners/managers participated in entrepreneurship/business training, the finding shows that training has a positive but insignificant effect on the performance of MSEs. This may be since the type of training given to the entrepreneur were not be able to enhance their skills. Owners or managers age have a positive and significant effect on sales volume and employment. The mean age of the owners-managers is 26.5 years and the average business age of MSEs is about 4.75 years. This implies that MSEs owners in this age range are youths so that they are focusing on maximizing sales volume and creating additional employment opportunities instead of asset building. Loan repayment from financial institutions limits them to build assets but significantly influence the employment and sales performance of MSEs. The level of years of schooling of managers-owners have a significant and positive influence on the sales performance of MSEs. This implies that they can understand the ongoing business environment, may search for entrepreneurship training, and able to record the firms' account and manage appropriately since the average level of schooling is $9^{\text {th }}$ grade. The only demographic characteristics of owner/managers that have a positive and significant effect on the performance indicators are gender. Enterprises owned/managed by a male have relatively better performance on sales and employment of their firms than their female counterparts. The paired t-test result and the regression estimation reveals that there is a significant difference in the sales and employment performance between femaleowned and male-owned MSEs. Thus, the null hypothesis stating that there is no gender difference in the performance of MSEs was rejected and the alternative was accepted. The finding is similar to other studies ((Rosa, Carter, \& Hamilton, 1996; Robb, 2002; Kalleberg \& Leicht, 1991).

\section{Conclusions and Recommendations}

The findings from the effect of demographic factors of owners/managers on the performance of sale volumes of MSEs suggests that age of the owner/manager, year of schooling, and gender(male) have a positive and significant influence at $5 \%$ level of significance, while entrepreneurship training and marital status have a positive and 
insignificant effect. The study reveals that the age of the owner, gender(male), and marital status ( being single \& married) have a significant effect on employment performance of MSEs. Of the demographic factors of the owner/manager, gender is found to have a positive and significant impact on the sales and employment performance of MSEs.

The finding shows that the owners/managers characteristics have mixed-results in influencing the sales and employment performance of MSEs. Therefore, the research paper concludes that owners/managers demographic characteristics of entrepreneurs positively influences the performance of MSEs in Ethiopia. The researcher recommends that the government should strengthen its role in enriching youths in education both in coverage and quality, while the type and nature of training package given to MSEs owner's/managers should be redesigned and revisited.

\section{Limitations of the study and Future Research Suggestions}

The key limitation of the study is the dependability of data collected from MSEs operators who usually do not have the interest to provide the available information about their business for fear of being exposed to tax. Most of the MSEs operators don't have the habit of accounting and bookkeeping procedures so that they may supply inaccurate information during data collection. The results from the study rely on quantitative data collected through the use of semi-structured questionnaires. The findings would be further comprehensive if it includes more qualitative data to answer the reasons and how MSEs performance is impacted by demographic characteristics of owners/managers. Furthermore, the study is cross-sectional; i.e. it disregards MSEs and operators characteristics which could be examined using longitudinal study design. However, scientific procedures were employed to collect and analyze the data, which enables us to generalize our findings. In-depth studies should also be done on the factors that bring gender differences on the performance of MSEs. Future cross-sectional studies could employ both qualitative and quantitative research design or use longitudinal study for the detailed examination of the impact of demographic characteristics of owners/managers on the performance of MSEs.

\section{Practical Implications}

The study assesses the role of demographic characteristics of owners/managers in promoting and enhancing the performance of MSEs. MSEs operators could utilize managerial and entrepreneurship training provided by microfinance institutions and micro and small enterprises development office because it would enable them to acquire business management skills and knowledge. Strengthen the existing capacity of micro-credit institutions and micro and small enterprises development agencies are of paramount importance since the two institutions play a significant role in the growth of MSEs. Improving the modality of managerial and entrepreneurial training and strengthen women empowerment should be the focus of both micro and small enterprise development agencies and microfinance institutions of nations.

\section{Statement of Conflicting Interests}

There are no conflicts of interest regarding the publication of this article.

\section{Funding}

There is no financial support received for publication of this article.

\section{References}

Akabueze, B. (2002). Financing small and medium enterprises (SMEs):The Small and Medium Indusries Equity Investment Scheme (SMIEIS) Option.Lagos. Nigeria.

Aldaba, R. M. (2012). Small and Medium Enterprises ' (SMEs) Access to Finance: Philippines. In PIDS Discussion Paper Series (No. 05).

Amoah, S. K., \& Amoah, A. K. (2018). The Role of Small and Medium Enterprises (SMEs) to Employment in Ghana. International Journal of Business and Economics Research, 7(5), 151.

Amobi, A. . (2006). Entrepreneur human capital endowments and minority business viability. Journal of Human Resources, 20(4), 540-554.

Anne, J., Gichuki, W., Njeru, A., \& Tirimba, O. I. (2014). Challenges Facing Micro and Small Enterprises in Accessing Credit Facilities in Kangemi Harambee Market in Nairobi City County , Kenya. International Journal of Scientific and Research Publications, 4(12), 1-25.

Atiase, V. Y., Mahmood, S., \& Wang, Y. (2019). Does institutional logic matter in microfinance delivery? An empirical study of microfinance clients. International Journal of Entrepreneurial Behaviour and Research. https://doi.org/10.1108/IJEBR-10-2018-0713

Ayyagari, M., Asli, D.-K., \& Maksimovic, V. (2007). Firm Innovation in Emerging Markets:World Bank Policy Research Working Paper 4157.

Batsakis, G. K. (2014). Impediments on the way to entrepreneurship. Some new evidence from the EU's post- 
socialist world. Journal of Small Business and Enterprise Development, 21(3), 385-402. https://doi.org/10.1108/JSBED-04-2014-0062

Black, D. A., Noel, B. J., \& Wang, Z. (1999). On the Job Training, Establishment Size and Firm Size: Evidence for Economies of Scale in the Production of Human Capital. Southern Economic Journal, 66(1), 82-100.

Brush, G. (1992). Research on women business owners: past trends, a new perspective, future directions. Entrepreneurship Theory and Practice, 16(4), 5-30.

Bryan, J. (2006). Training and performance in small firms. International Small Business Journal, 24(6), 635-660.

Cochran, W. (1977). Sampling Techniques (3rd editio). New York: John Wiley \& Sons.

Creswell, J. W. (2014). Research Design:Qualtative, Quantitative, and mixed methods approaches (4th ed.). SAGE Publications Ltd.

Davidsson, P. (1991). "Continued Entrepreneurship - Ability, Need, and Opportunity As Determinants of Small Firm Growth,." Journal of Business Venturing, 6(6), 405-429.

Du Rietz, A., \& Henrekson, M. (2000). Testing the female underperformance hypothesis. Small Business Economics, 14(1), 1-10.

Fapohunda, T. . (2013). Gender differences in human capital and personality traits as drivers of gender gap in entrepreneurship: Evidence from Nigeria. British Journal of Economics Management and Trade, 3(1), 3047.

FeMSEDA. (2011). Government of the Federal Democratic Republic of Ethiopia Micro and Small Enterprise Development Strategy, provision framework and methods of Implementation (Approved). Addis Ababa.

Frese, M. (2000). Success and failure of microbusiness owners in Africa: A psychological approach. Quorum Books/Greenwood Publishing Group.

García, M. (2005). Training and business performance: The Spanish case. International Journal of Human Resource Management, 16(9), 1691-1710.

Gottschalk, S., \& Niefert, M. (2012). Gender differences in business success of German start-up firm. International Journal of Entrepreneurship and Small Business, 18(1), 15-46.

Hall, G. (1995). Surviving and Prospering in the small firm sector. London: Routledge.

Harada, N. (2003). "Who success as an entrepreneur? An analysis of the post-entry performance of new firms in Japan", Japan and World Economy, 15(2), 211-222.

Kalleberg, A., \& Leicht, K. (1991). Gender and organizational performance: determinants of small business survival and success. Academy of Management Journal, 34(1), 136-161.

Katua, N. T. (2014). Role of SMEs in employment creation and economic growth in selected countries. International Journal of Education and Research, 2(12), 461-472.

Kirby, A. (2003). Entrepreneurship. Maidenhead: MCGraw-Hill Education.

Koch, M. J., \& McGrath, R. G. (1996). Improving Labour Productivity: Human Resource Management Policies Do Matter. Strategic Management Journal, 17(5), 332-54.

Kothari, C. R. (2009). Research Methodology_Methods_and_Techniques (2nd ed.). New Age Publications.

Littunen, H., \& Virtanen, M. (2006). Differentiating growing ventures from non-growth. The International Entrepreneurship and Management Journal, 2(1), 93-109.

Lucas, R. E. (1993). Making a Miracle. Econometrica, 61(2), 251-272.

Mahmood, R., \& Rosli, M. M. (2013). Microcredit position in micro and small enterprise performance: the Malaysian case. Management Research Review, 36(5), 436-453.

Mba, N. (2006). 'Women and politics in colonial Nigeria', paper presented at the Symposium on the Impact of Colonialism on Women in Nigeria Women's Research Documentation Centre, Institute of African Studies, University of Ibadan, 16-18th October.

Mescon, T. S. (1987). The entrepreneurial institute: education and training for minority small business owners. Journal of Small Business Management, 25(1), 61-66.

Mugenda, O., \& Mugenda, G. (2003). Research methods: Quantitative and qualitative approaches. Nairobi: Nairobi Act Press.

NBE. (2016). National Bank Of Ethiopia Annual Report. Addis Ababa.

Oyelaran-Oyeyinka, B. (2006). Learning to Compete in Africa Industry: Institutions and Technology in Development. Farnham: Ashgate Publishing.

Robb, A. (2002). Entrepreneurial performance by women and minorities: the case of new firms. Journal of Developmental Entrepreneurship, 7(4), 383-397.

Rosa, P., Carter, S., \& Hamilton, D. (1996). Gender as a determinant of small business performance: insights from a British study. Small Business Economics, 8, 463-478.

Shane, S. (2007). A general theory of entrepreneurship: The individual-Opportunity Nexus. Aldershot: Edward Elgar.

Shava, H., \& Rungani, E. C. (2016). Influence of gender on SME performance in emerging economies. Acta Commercii - Independent Research Journal in the Management Sciences, 16(1). 
https://doi.org/10.4102/ac.v16i1.408

Storey, D. J. (1994). New Firm Growth and Bank Financing. Small Business Economics, 6(2), 139-150.

Taiwo, M. A., Ayodeji, A. M., \& Yusuf, B. A. (2013). Impact of Small and Medium Enterprises on Economic Growth and Development. American Journal of Business and Management, 2(1), 18. https://doi.org/10.11634/21679606170644

Tendai, C. (2014). Entrepreneurship education in South Africa. Mediterranean Journal of Social Sciences, 5(2), 403-416.

Webster, B., Walker, E., \& Brown, A. (2005). Australian small business participation in training activities. Education and Training, 47(8-9), 552-561.

\section{Appendix}

Appendix -1:Results of t-test for equality of means by gender on level of sales

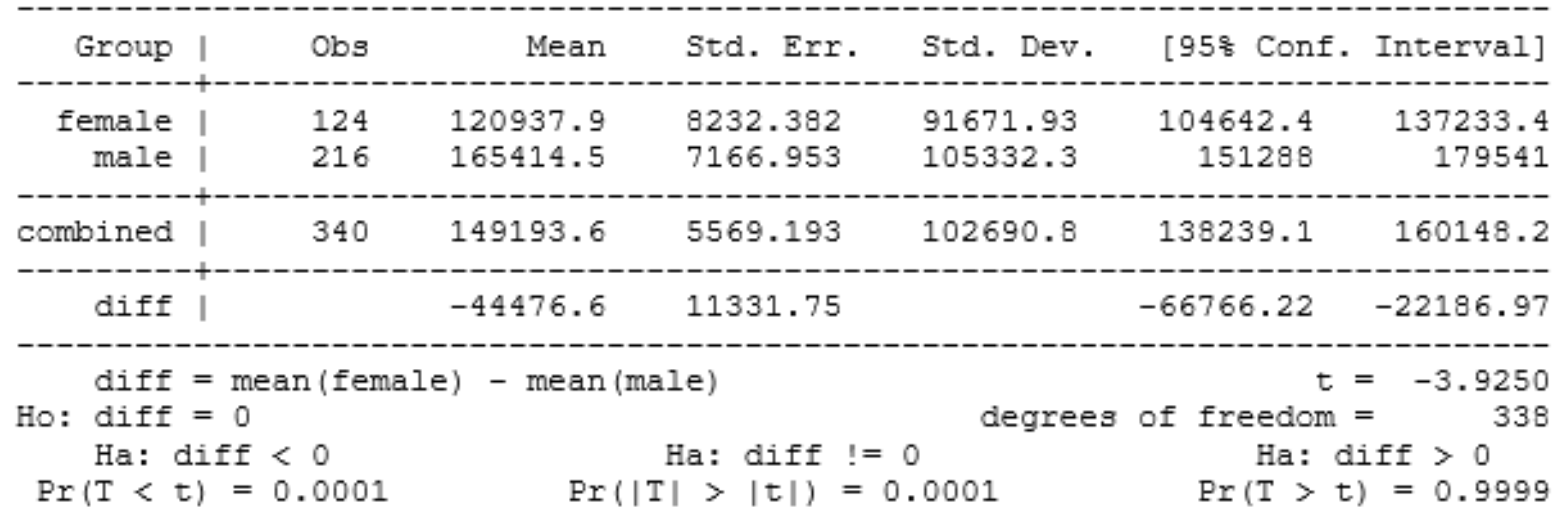

Appendix-2:Results of t-test for equality of means by gender on level of employment

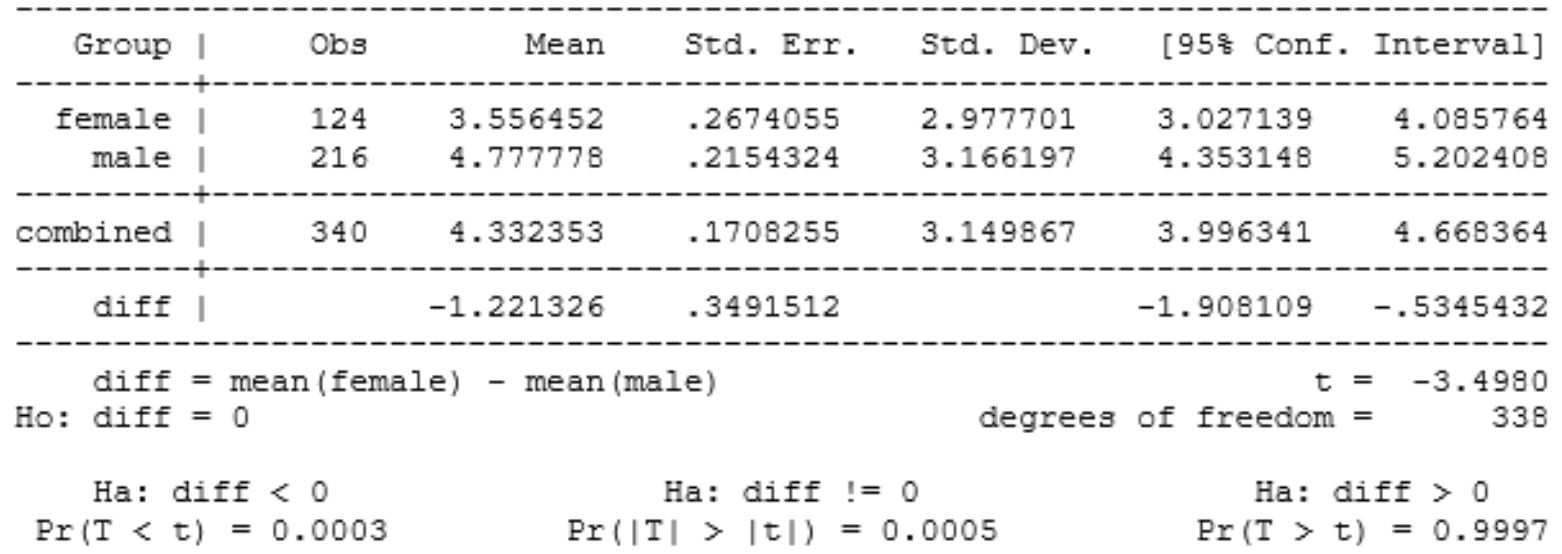

